Tropical Journal of Pharmaceutical Research April 2011; 10 (2): 169-176

(C) Pharmacotherapy Group,

Faculty of Pharmacy, University of Benin,

Benin City, 300001 Nigeria.

All rights reserved.

Research Article

Available online at http://www.tjpr.org

\title{
Effect of the Aqueous Extract of Gloriosa superba Linn (Langli) Roots on Reproductive System and Cardiovascular Parameters in Female Rats
}

\author{
Arati A Malpani ${ }^{1}$, Urmila M Aswar ${ }^{2}$, Shiv K Kushwaha ${ }^{2}$, GN \\ Zambare $^{2}$ and SL Bodhankar ${ }^{2 *}$ \\ ${ }^{1}$ Department of Pharmacology, HKES's College of Pharmacy, Sedam Road, Gulbarga 585105, ${ }^{2}$ Department of \\ Pharmacology, Bharati Vidyapeeth University, Poona College of Pharmacy, Erandawane, Paud Road, Pune- \\ 411038, India
}

\begin{abstract}
Purpose: Gloriosa superba Linn (liliaceae) has been used to induce labor in the traditional Indian system of medicine. The objective of the study was to evaluate the activity of the aqueous extract of Gloriosa superba $(A L)$ root on the female reproductive system of rat.

Methods: The aqueous extract of Gloriosa superba was prepared by simple maceration. Phytochemical analysis as well as toxicity (in mice) and antifertility studies, uterotrophic assay, duciduoma model, uterotonic assessment in-vitro and in-vivo of aqueous extract was carried out in rats. Oxytocin was used as the uterotonic reference standard. The effect of the extract on cardiovascular parameters was also evaluated.

Results: Phytochemical analysis shows presence of flavonoids, tannins, alkaloids, and glycosides in the aqueous extract of Gloriosa superba. The extract yield was $6 \%$ and was found to be was safe at a dose as high as $550 \mathrm{mg} / \mathrm{kg}$ body weight. Antifertility study showed early abortificient activity. No increase in uterus and ducidual weight was observed. Both the reference (oxytocin) and the extract produced dosedependent contractions but the extract had no effect on heart parameters and blood pressure.

Conclusion: The aqueous extract of Gloriosa superba showed oxytocic activity and early abortifacient activity which may be due to the presence of alkaloids such as colchicine. This provides justification for its use in traditional medicine.
\end{abstract}

Keywords: Abortificient activity; Blood pressure; Gloriosa superba; Oxytocic activity 


\section{INTRODUCTION}

Most of the plants claimed to be oxytocics are used to induce and maintain labour, aid the removal of retained placenta, regulate postpartum bleeding and as abortifacient. The plant extracts increase the spontaneous activity of the uterus causing increase in contractions [1]. Some animal products have also been used to induce labour and removal of retained placenta, e.g., Hippopotamus amphibious (skin and meat) and Panthera leo (fats and faeces) which are boiled and the cooled decoction administered orally. Medicinal plants used to speed the birth process are usually administered towards the end of the gestation period or at the onset of labour labor pains. Plants that produce uterine contractions have a similar action to that of oxytocin which stimulates the uterus, causing strong contractions, and thus producing labour [2]. Traditional birth attendants, mothers-in-law, mothers and the expectant mother mostly prescribe these herbal remedies to induce labour. Some of these medicinal plants are also fed to cows and goats in labour.

Gloriosa superba L., (Langli), is widely distributed in the tropical jungles of Africa and in many parts of tropical Asia, including India, Burma, Malaysia and Srilanka[10]. In India, it is mainly found in Nasik, Ratnagiri and Savanthwadi in Maharashtra state; Uttar Kannada, Hassan, Chikmangalur, Coorg and Mysore in Karnataka state; Cannanore, Palakkad and Trivandrum in Kerala state; as well as in Tamil Nadu and Goa. It is an erect, perennial, climbing herb. Tribesmen of Patalkot apply the rhizome extract over the navel and vagina to induce labour and facilitate normal delivery. According to them, 250 to $500 \mathrm{mg}$ of the extract may lead to abortion if given to a lady with a pregnancy of 1 - 2 months [3]. It is also used for the treatment of ulcers, leprosy, piles, inflammations [4], intestinal worm infestations, thirst, bruises, skin problems and snakebite [5,6]. Although some pharmacological studies have been carried out on this plant [7], to the best of our knowledge, there is no report on its effect on the reproductive system. In view of its folkloric use, the first objective of this study was to evaluate the effect of the aqueous extract of the root of Gloriosa superba L. on the reproductive system of rat. Since hypertension is one of the most common medical problems encountered during pregnancy, causing complications in $2-3 \%$ of pregnancies [8], the second objective was to determine the effect of the extract on some cardiovascular parameters.

\section{EXPERIMENTAL}

\section{Materials}

Histamine and estrogen benzoate $(1 \mathrm{mg} / \mathrm{ml}$, Himedia Labs, India); hydroxyprogesterone caproate (German Remidies, India); oxytocin injection (Ranbaxy Laboratories Limited, India), adrenaline bitartarate and atropine sulphate injection (T. Walker's Pharmaceuticals Pvt. Ltd, Pune, India); and DeJalons solution (comprising $9.0 \mathrm{~g}$ of $\mathrm{NaCl}, 4.2$ $\mathrm{ml}$ of $10 \% \mathrm{KCl}, 0.27 \mathrm{ml}$ of $1 \mathrm{M} \mathrm{CaCl}_{2}, 0.5 \mathrm{~g}$ of glucose and $0.5 \mathrm{~g}$ of $\mathrm{NaHCO}_{3}$ in $1 \mathrm{~L}$ of distilled water) were the main materials used.

\section{Collection and identification of plant material}

The roots of Gloriosa superba L. were collected from a local market in Pune City, Maharashtra, India and authenticated by $\operatorname{Dr} A$ M Mujumdar a taxonomist and Head, Plant Sciences Division, Agharkar Research Institute, Pune, Maharashtra, India. The plant specimen was deposited in the herbarium of Agharkar Research Institute, Pune, India (voucher no. ARI/PG/897).

\section{Animals}

All the animal experiments were performed on in-bred adult female Wistar rats (weighing $250-300 \mathrm{~g})$. They were maintained at a temperature of $25 \pm 1^{\circ} \mathrm{C}$ and relative humidity of $45-55 \%$ under $12 \mathrm{~h}$ light/12h dark cycle. 
The animals had free access to food pellets (Chakan Oil Mills, Pune, India) and water. The experimental protocol was approved by the Institutional Animal Ethics Committee (IAEC) of Poona College of Pharmacy, Pune, India, (approval ref no. CPCSEA/32/2008) and followed the guidelines of India's Committee for the Purpose of Control and Supervision of Experiments on Animals (CPCSEA) [22].

\section{Preparation of extract}

Gloriosa superba root powder (100 g) was defatted with $150 \mathrm{ml}$ of petroleum ether (b.p. $40-60 \stackrel{\circ}{\circ}$ ). Cold maceration by addition of distilled water $(150 \mathrm{ml})$ to dried, defatted Gloriosa superba root powder was carried out for $24 \mathrm{~h}$ in a flask using a mechanical shaker. The supernatant was removed, the marc dried and again macerated with $150 \mathrm{ml}$ of distilled water for $24 \mathrm{~h}$. The extract was filtered through Whatman filter paper no. 44 and dried in a tray dryer at $30^{\circ} \mathrm{C}$. The yield was $6 \%$. The extract was reconstituted in distilled water prior to pharmacological tests.

\section{Preliminary phytochemical tests}

The extract was analyzed for phytochemicals including steroids using Salkowski test [9], flavonoids and tannins using ferric chloride test [10], alkaloids by Mayer's test [11], and proteins and glycosides by Biuret and Legal tests, respectively $[12,13]$.

\section{Acute oral toxicity study}

For acute oral toxicity and $\mathrm{LD}_{50}$ determination, OECD (Organization for Economic Cooperation and Development) guideline AOT-425 was followed [14]. Healthy adult Swiss mice of either sex weighing between 20 - $25 \mathrm{~g}$ were used for acute oral toxicity study. Food, but not water, was withheld for $4 \mathrm{~h}$ before the drug was administered orally. The test drug was given in doses of $5000,1750,550 \mathrm{mg} / \mathrm{kg} \mathrm{p.o.;} \mathrm{the}$ number of mice per dose was three. The mice were observed for $2 \mathrm{~h}$ for behavioural, neurological and autonomic profiles and for any lethality or death over the next $48 \mathrm{~h}$.

\section{Assessment of antifertility activity of extract}

Adult female Wistar rats were kept overnight with male rats of proven fertility (in the ratio of 2 females to 1 male) and the vaginal smear of the female rats was examined for spermatozoa in the morning. The day on which the spermatozoa were observed in the smear was considered as day zero of pregnancy (Day 0) and such female rats were divided into four groups of 5 rats each. Group-I (Control) received the vehicle (distilled water), while the other groups received extract as follows: Group-II (50 $\mathrm{mg} / \mathrm{kg}$ ), Group-III (100 mg/kg), and Group-IV $(200 \mathrm{mg} / \mathrm{kg})$. The rats received these treatments daily for 7 days. On day 10, all the animals were laprotomized under light ether anesthesia and the number of implantation sites in both horns of the uteri was recorded. Pregnancy parameters such as length of pregnancy (days), pregnancy index (i.e., no. of pups delivered/no. of implants, expressed as a percentage), no. of pups on day 7 and teratogenicity were recorded [15].

\section{Determination of estrogenic activity of extract}

Immature female rats $(50-80$ g) were bilaterally ovariectomized under light ether anesthesia [16]. The animals were classified into different groups (6 each). Group-I (control) was control while groups II - IV received the extract $-50,100$ and $200 \mathrm{mg} / \mathrm{kg}$, respectively; Group- $\mathrm{V}$ received $0.1 \mathrm{mg}$ estradiol benzoate in olive oil (subcutaneously) biweekly. The treatment period was 28 days. On day 29, the animals were sacrificed and dissected, their uteri removed and freed from surrounding tissues, blotted on filter paper and then weighed quickly on an electronic balance. 


\section{Determination of progestogenic activity}

The deciduoma model was used for this experiment [17]. Adult female Wistar rats weighing 200 to $250 \mathrm{~g}$ were ovariectomized. The animals were classified, according to the extract (unless otherwise specified) dose given, as follows: Group-I (Control, vehicle, i.e., distilled water), Group-II (hydroxyprogesterone caproate (reference, 0.04 mg/animal, s.c.), Group-III (AL-50 mg/kg), Group-IV (AL-100 mg/kg), Group-V (AL-200 $\mathrm{mg} / \mathrm{kg}$ ). One week later, all the animals were treated with $0.5 \mu \mathrm{g}$ estradiol/animal once daily s.c. for 4 days, followed by progesterone (Group-II) or extract (Groups-III to $V$ in doses of 50,100 and $200 \mathrm{mg} / \mathrm{kg}$, respectively) and vehicle (control group) for 9 days. The animals were anaesthetized, the uterus of each rat exposed on day 5 of the preceding treatment, and then $1 \mathrm{mg}$ histamine dihydrochloride injected into the lumen of the left horn. The animals were sacrificed thereafter and the left uterine horn from each animal removed and weighed. The degree of deciduoma formation was evaluated as percent increase in the weight of the histamine-injected uterine horn, compared with the control horn..

\section{In-vivo assay of uterotonic activity of extract}

Microballoon technique was used for this assay. Adult female Wistar rats weighing 250 to $300 \mathrm{~g}$ were divided into two groups each containing six animals, and primed with 100 $\mu \mathrm{g}$ of estradiol benzoate s.c. $24 \mathrm{~h}$ prior to the experiment. The rats showing estrous phase were selected for the experiment. Each animal was anaesthetized with urethane $(1.25 \mathrm{~g} / \mathrm{kg})$ and the jugular vein cannulated for drug administration. A small incision was made on the lower abdominal skin and the uterus exposed. Another small incision was made near the midrostral end of the left uterine horn. A saline-filled catheter with a microlatex balloon on its end (approx $2 \mathrm{~cm}$ diameter) was inserted into the lumen of the uterine horn and secured to it by stitching
[18]. The catheter was connected to a pressure transducer and normal uterine contractions were recorded using an 8channel recorder (Power Lab, model 8/30, AD Instruments, Australia). The extract (0.2, 0.4 or $0.8 \mathrm{mg} / \mathrm{kg}$, i.v) and oxytocin $(0.2,0.4$ or $0.8 \mu \mathrm{g} / \mathrm{kg}$, i.v) were administered to two different groups of female rats. The dose responses of oxytocin (reference) and the extract were recorded until a ceiling effect was observed.

\section{In-vitro assay of uterotonic activity of extract}

Adult female Wistar rats weighing 120 to 200 $\mathrm{g}$ were primed with $100 \mathrm{\mu g}$ of estradiol benzoate s.c. $24 \mathrm{~h}$ prior to the experiment. The rats showing estrous phase were selected for the experiment, sacrificed by cervical dislocation and the uterus was removed. One horn of the uterus was mounted on an organ bath containing DeJelon's solution and allowed to stabilize for 45 min during which the tissue was washed at least 4 times with fresh De-Jelon's solution. Dose response was recorded for oxytocin $(0.05-0.8 \mu \mathrm{g})$ and the extract $(0.1$ $6.4 \mathrm{mg}$ ) until a ceiling (peak) effect was observed. The response of the extract was compared with that of oxytocin (reference) response [19].

Effect of extract on blood pressure (BP) and electrocardiogram (ECG) of female rat

Adult female Wistar rats weighing 200 to 250 $\mathrm{g}$ were anesthetized with urethane (1.25 $\mathrm{g} / \mathrm{kg}$ ) and the jugular vein cannulated for administration of the extract. The carotid artery was cannulated for the recording of blood pressure (BP) while electrocardiogram (ECG) electrodes were attached to the right and left forelimb and right hindlimb for recording of ECG. ECG, BP and heart rate were recorded using an 8-channel recorder (Powerlab model 8/30, AD Instruments, Australia).

Trop J Pharm Res, April 2011;10 (2):172 
Table 1: Antifertility activity of Gloriosa superba $(A L)$ extract in female Wistar rats

\begin{tabular}{|c|c|c|c|c|c|c|c|c|}
\hline $\begin{array}{l}\text { Extract } \\
\text { dose } \\
(\mathrm{mg} / \mathrm{kg})\end{array}$ & $\begin{array}{l}\text { No. of rats } \\
\text { showing } \\
\text { presence } \\
\text { of } \\
\text { spermato- } \\
\text { zoa }\end{array}$ & $\begin{array}{l}\text { No. of } \\
\text { rats } \\
\text { showing } \\
\text { implanta- } \\
\text { tion on } \\
\text { day } 10\end{array}$ & $\begin{array}{l}\text { No. of } \\
\text { implants } \\
\text { in rats }\end{array}$ & $\begin{array}{l}\text { No. of } \\
\text { pups }\end{array}$ & $\begin{array}{l}\text { Reducti } \\
\text { on in } \\
\text { pregnan } \\
\text {-cies (\%) }\end{array}$ & $\begin{array}{l}\text { No. of } \\
\text { deaths } \\
\text { during } \\
\text { pregnancy }\end{array}$ & $\begin{array}{l}\text { Gestation } \\
\text { period } \\
\text { (days) }\end{array}$ & $\begin{array}{l}\text { Pregnancy } \\
\text { index }\end{array}$ \\
\hline Control & 6 & 6 & 54 & 55 & 0 & 0 & $21.5 \pm 0.2$ & $101.9 \pm 0.0$ \\
\hline 50 & 5 & 5 & 47 & $33^{\star \star *}$ & 0 & 1 & $21.4 \pm 0.2$ & $90 \pm 0.0^{*}$ \\
\hline 100 & 5 & 5 & 51 & $42^{*}$ & 0 & 0 & $21.6 \pm 0.2$ & $72.7 \pm 0.0^{\text {*** }}$ \\
\hline $\mathrm{AL}(200)$ & 6 & 3 & $33^{\star \star \star}$ & $24^{\star \star *}$ & 50 & 0 & $21.7 \pm 0.3$ & $82.2 \pm 0.0^{* \star \star}$ \\
\hline
\end{tabular}

$p^{*}<0.01,{ }^{* *} p<0.001,{ }^{* * *} p<0.0001$ compared with control group.

\section{Statistical analysis}

The arithmetic means of the data were calculated for each experiment. The results were subjected to statistical analysis using one-way analysis of variance followed by Dunnett's test. The level of significance used was $p<0.05$. The statistical software used was Graph Pad Prism, USA, versions 4 and 5.

\section{RESULTS}

Preliminary phytochemical assessment showed that the aqueous extract of roots of Gloriosa superba contains flavonoids, tannins, alkaloids and glycosides, while acute toxicity studies indicate that the extract was safe up to a dose level of $550 \mathrm{mg} / \mathrm{kg}$ of body weight.

\section{Antifertility activity of extract}

The antifertility data for the extract are shown in Table 1. The reduction in pregnancies, based on the number of rats showing implants on day 10 of laprotomy was $0 \%$ for control and all extract doses except for 200 $\mathrm{mg} / \mathrm{kg}$ which was $50 \%(p<0.05)$. The extract reduced the number of pups born when compared to the number of implants present in the uterus on day 10 of laprotomy. The reduction was significant for all three doses of the extract. However, none of the test animals from days $1-22$ of pregnancy irrespective of the treatment received.
Gestation period was approximately 21 days for all the animal groups and all the pups born survived up to the $7^{\text {th }}$ post-natal day, the number being, 8 or 9 per group. Pregnancy index (PI) of the control group was $101.9 \%$ while for extract groups, it was $90(50 \mathrm{mg} / \mathrm{kg}$, $p<0.01), 72.7$ (100 mg/kg, $(p<0.0001)$. and $82.2 \%$ (200 mg/kg, $p<0.0001)$, respectively.

\section{Effect of $G$. superba (AL) extract on uterus weight}

Table 2 shows the effect of the extract on the uterus weight of immature female rats. The administration of estradiol benzoate provoked a significant increase $(p<0.001)$ in uterus weight compared with control while extract administration (all doses) did not increase uterus weight significantly. Similarly, while administration of hydroxyprogesterone capro-

Table 2: Effect of $A L$ extract on uterus weight (mean \pm SEM)

\begin{tabular}{lll}
\hline Treatment & $\begin{array}{l}\text { Uterus weight } \\
(\mathbf{m g})\end{array}$ & $\begin{array}{l}\text { Decidual } \\
\text { (uterine horn) } \\
\text { weight }(\mathbf{m g})\end{array}$ \\
\hline Control & $90.5 \pm 8.8$ & $187.6 \pm 36.6$ \\
Estrogen & $404.5 \pm 34.7^{\star *}$ & -- \\
$(1 \mathrm{mg} / \mathrm{kg})$ & & \\
$\mathrm{AL}(50 \mathrm{mg} / \mathrm{kg})$ & $59.8 \pm 5.2$ & $132.0 \pm 12.4$ \\
$\mathrm{AL}(100 \mathrm{mg} / \mathrm{kg})$ & $70.0 \pm 4.6$ & $187.0 \pm 41.1$ \\
$\mathrm{AL}(200 \mathrm{mg} / \mathrm{kg})$ & $79.6 \pm 5.8$ & $183.5 \pm 25.5$ \\
Progesterone & - & $340.0 \pm 24.1^{*}$ \\
$(1 \mathrm{mg} / \mathrm{kg})$, & &
\end{tabular}

${ }^{*} p<0.01,{ }^{* *} p<0.001$ compared with control group. 
ate significantly increased $(p<0.01)$ the weight of uterine horn, the extract, at all doses, did not; although the $50 \mathrm{mg} / \mathrm{kg}$ appeared to have reduced the weight of the uterine horn, this was not statistically significant.

\section{Effect of $G$. superba extract $(A L)$ on rat uterine contractility}

Fig 1 shows the spasmogenic activity (i.e., contraction) of the rat uterus of the extract in estrogen-primed non-pregnant uterus in-vivo while Fig 2 indicates the same parameter in vitro.

The extract treatments produced increase in uterine contractility both in vivo and in vitro but height of contractions produced by the extract was slightly less than that produced.

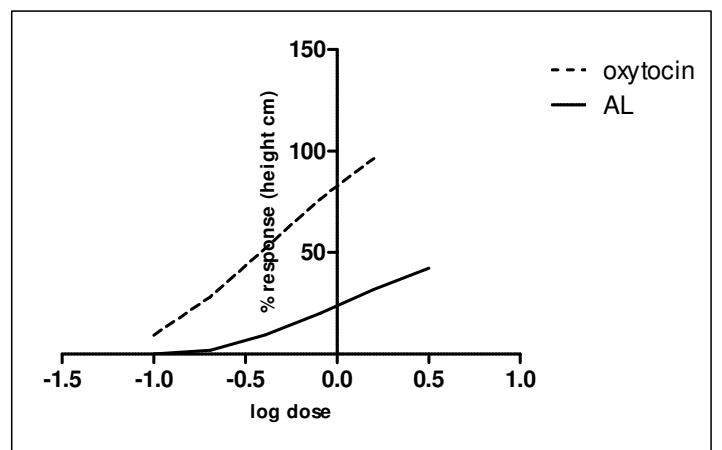

Figure 1: In-vivo effect of $G$. superba extract $(\mathrm{AL})$ and oxytocin (reference) on rat uterine contractions

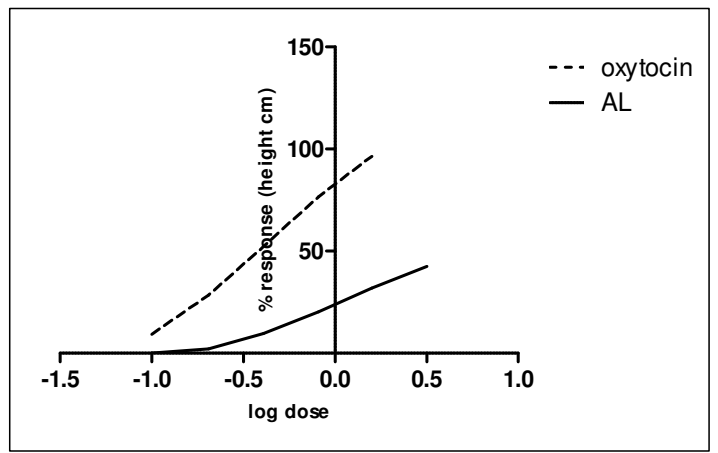

Figure 2: In-vitro effect of $G$. superba extract $(A L)$ and oxytocin (reference) on rat uterine contractions

\section{Effect of G. superba (AL) extract on rat cardiovascular parameters}

Table 3 indicates that the extract had no significant effect on rat blood pressure and heart rate when compared with the control group.

Table 3: Effect of $G$. superba extract (AL) on cardiovascular parameters of rat (mean \pm SEM)

\begin{tabular}{lllll}
\hline Parameter & Control & \multicolumn{3}{c}{ Extract dose } \\
\cline { 3 - 5 } & & $\mathbf{0 . 2 m g} / \mathbf{k} \mathbf{0 . 4 m g} / \mathbf{k g} \mathbf{0 . 8 m g /}$ \\
& & $\mathbf{g}$ & & $\mathbf{k g}$ \\
\hline Blood pres- & $83.5 \pm$ & $83.5 \pm$ & $83.5 \pm$ & $83.5 \pm$ \\
sure $(\mathrm{mmHH})$ & 5.8 & 5.8 & 5.7 & 5.72 \\
Beats/min & $268.3 \pm$ & $268.3 \pm$ & $268.3 \pm$ & $268.3 \pm$ \\
& 25.1 & 25.1 & 25.1 & 25.13 \\
QT interval & $0.065 \pm$ & $0.065 \pm$ & $0.065 \pm$ & $0.065 \pm$ \\
& 0.003 & 0.003 & 0.004 & 0.004 \\
\hline
\end{tabular}

\section{DISCUSSION}

The persistent use of plants by pregnant women and traditional birth attendants for the induction of labor suggests that some herbs might be potent uterine stimulants. Therefore, studies of such herbs could provide a helpful guide to the discovery of new oxytocics. Gloriosa superba is used for labour induction by traditional birth attendants in India.

Phytochemical analysis of the extract showed presence of flavonoids, tannins, alkaloids, and glycosides in the aqueous extract of Gloriosa superba. The extract $(\mathrm{AL})$ was safe up to a dose of $550 \mathrm{mg} / \mathrm{kg}$ which is approx. 10 times higher than the minimum dose at which the extract effectively reduced the number of pups produced. While the extract had significant anti-implantation and early abortifacient activities, gestation period and pregnancy index were not altered, the extract did not show any apparent teratogenicity as the pups born seemed normal and no death occurred during the 7-day observation period.

It is well known that for implantation to take place, the exact equilibrium of estrogen and progesterone must obtain, and hence any disturbance in the level of these hormones 
may cause abortion or infertility. In order to determine the mechanism of abortifacient activity of the extract, two hormones, progesterone and estrogen, which have the capacity for termination/reduction of pregnancy were used in the study to ascertain whether the extract exhibits estrogenic and progestogenic activities. The failure of the extract to increase the uterine weight suggests absence of estrogenic activity. Similarly, progestogenic activity was not manifest as the extract did not increase decidual (uterine horn) weight.

The uterine contractility of the extract may be due to its oxytocic effects. The effect was fast in onset and could be totally eliminated by washing with extract-free Dejalon solution, thus suggesting the presence of low molecular weight active compound(s) in the extract, which may have penetrated rapidly to the site of action.

However, the extract demonstrated spasmogenic activity, which was not as strong as that of oxytocin, Thus, its antiimplantation and early abortifacient activity may be due to its oxytocic property. The ability to cause uterine contractility raises the possibility of its being developed as a medicine for induction of labour. Since many pregnancies are associated with gestational hypertension, it is worth noting that the extract had no effect on blood pressure and other cardiovascular parameters measured.

\section{CONCLUSION}

The tests carried out on $G$. superba extract indicate that its mechanism of action was neither estrogenic nor progesterone like. However, its early abortifacient activity appears to suggest that its activity is oxytocic. Nonetheless, further studies are required to determine which phytochemical constituents are responsible for the plant's abortifacient and oxytocic activities. The absence of any effects on the cardiovascular parameters enhances the plant extract's safety profile in pregnancy. Overall, the study lends some credence to the folkloric use of Gloriosa superba Linn. (Langli) in labour induction.

\section{ACKNOWLEDGEMENT}

The authors are thankful to the Vice Chancellor, Dr. SS Kadam, and Principal, Dr KR Mahadik, of Bharati Vidyapeeth University, Poona College of Pharmacy, Pune for providing resources and facilities for this research work.

\section{REFERENCES}

1. Kamatenesi-Mugisha $M$, Oryem-Origa $H$. Medicinal plants used to induce labour during childbirth in western Uganda. J. Ethnopharmacol. 2007; 109(1): 1-9.

2. Pamplona-Roger G. Encyclopedia of Medicinal Plants, Vol 2. Education and Health Library, Editorial Safeliz, SL, Spain. 2000.

3. Maurya $R$, Srivastava $S$, Kulshreshta D, Gupta C. Traditional remedies for fertility regulation. Current Med. Chem. 2004; 11(11): 1431-1450.

4. Kala $C$, Farooquee $N$, Dhar $U$. Prioritization of medicinal plants on the basis of available knowledge, existing practices and use value status in Uttaranchal, India. Biodiversity and Conservation. 2004; 13(2): 453-469.

5. Mors W, Célia do Nascimento $M$, Ruppelt PB, Alvares PN. Plant natural products active against snake bite-the molecular approach. Phytochem. 2000; 55(6): 627-642.

6. Bhargava N. Ethnobotanical studies of the tribes of Andaman and Nicobar Islands, India. I. Onge. Economic Botany. 1983; 37(1): 110-119.

7. John J, Fernandes J, Nandgude $T$, Niphade $S$, Savla A, Deshmukh P. Analgesic and antiinflammatory activities of the hydroalcoholic extract from Gloriosa superba Linn. Intl. J. Green Pharm. 2009; 3(3): 215-219

8. Sibai B. Chronic hypertension in pregnancy. Obs. Gyncol. 2002; 100(2):369-377

9. Longanga $O A$, Vercruysse $A$, Foriers $A$. Contribution to the ethnobotanical, phytochemical and pharmacological studies of traditionally used medicinal plants in the treatment of dysentery and diarrhoea in Lomela area, Democratic Republic of Congo (DRC). J. Ethnopharmacol. 2000; 71(3): 411423.

10. Martin J, Martin M. Tannin assays in ecological studies: lack of correlation between phenolics, proanthocyanidins and protein-precipitating constituents in mature foliage of six oak species. Oecologia 1982; 54(2): 205-211.

11. Farnsworth $N$. Biological and phytochemical screening of plants. J. Pharm. Sci. 1966; 55(3): 225-276

12. Kumar G, Banu Z, Murugesan A, Pandian Z. Preliminary Toxicity and Phytochemical Studies of Aqueous Bark Extract of Helicteres isora L. Intl. J. Pharmacol. 2007; 3(1): 96-100. 
13. Tanira M, Shah A, Mohsin A, Ageel A, Qureshi S. Pharmacological and toxicological investigations on Foeniculum vulgare dried fruit extract in experimental animals. Phytotherapy Res. 1996; 10(1): 33-36.

14. Organization for Economic Cooperation and Development. Paris, France. 2001.

15. Bodhankar S, Garg S, Mathur VS. Antifertility screening of plants ART IX: Effect of five Indigenous plants on early pregnancy in female rats. Indian J Med Res. 1974; 62: 831.

16. Arjmandi B, Alekel L, Hollis B, Amin D, StacewiczSapuntzakis M, Guo P, Kukreja S.. Dietary soybean protein prevents bone loss in an ovariectomized rat model of osteoporosis. J. Nutr. 1996; 126(1): 161-167

17. Ohta Y. Deciduoma formation in rats ovariectomized at different ages. Biol Reprod. 1982; 27: 308-311.
18. Roth-Brandel U, Bygdeman M, Wiqvist $N$. Effect of Intravenous Administration of Prostaglandin E1 and F2 on the Contractility of the NonPregnant Human Uterus in Vivo. Acta Obstet Gynecol Scand. 1970; 49(S5): 19-25.

19. Vane J, Williams $K$. The contribution of prostaglandin production to contractions of the isolated uterus of the rat. Br. J.Pharmacol. 1973; 48(4): 629-639.

20. Posey D. Commodification of the sacred through intellectual property rights. J. Ethnopharmacol. 2002; 83(1-2): 3-12.

21. Bowman W, Rand $M$. Principles of drug action. Textbook of Pharmacology. Oxford: Blackwell Scientific; 1980; $p$ 19-22p.

22. CPCSEA. "CPCSEA guidelines for laboratory animal facility. Indian J Pharmacol. 2003; 35: 257-274. 